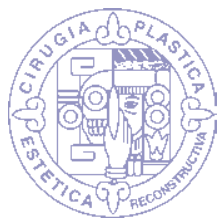

\title{
The importance of reducing the viral load to diminish the risk of COVID-19 spread
}

\author{
La importancia de reducir la carga viral para disminuir \\ el riesgo de contagio por COVID-19 \\ Jesús Cuenca-Pardo MD,* Guillermo Ramos-Gallardo MD,* \\ Estela Vélez-Benítez MD, * Carlos de J Álvarez-Díaz MD, ${ }^{\ddagger}$ \\ Javier Bucio-Duarte MD, * Rufino Iribarren-Moreno MD,* \\ David Rodríguez-Marín MD, ${ }^{\S}$ Livia Contreras-Bulnes MD*
}

\footnotetext{
Keywords: SARS-CoV-2, COVID-19, viral load, contagion, prophylactic care, face masks.

Palabras clave: SARS-CoV-2, COVID-19, carga viral, contagio, cuidados profilácticos, mascarillas faciales.
}

\footnotetext{
${ }^{*}$ Member of the Security Committee of the Mexican Association of Plastic, Aesthetic and Reconstructive Surgery. ₹ Assessor. Mexican Association of Plastic, Aesthetic and Reconstructive Surgery. $\S$ Biomedical Engineering. National Women's Institute.

Received:

September 17, 2020 Accepted to publish: September 20, 2020
}

\section{ABSTRACT}

We carried out a systematic review on the importance of reducing viral load, as a strategy to reduce the risk of infection or to diminish the severity of the disease. We selected 113 publications and analyzed the theoretical concepts and recommendations we made with the best medical evidence available. Viral load is related to the attack rate and severity of COVID-19. It has been recognized that the production of aerosols is the main source of contagion among health personnel. The risk of contagion is higher in closed and poorly ventilated spaces, where people stay with several individuals for a long time, without due distance and without protection. The contagion rate is higher than $80 \%$ and there is a very high mortality. Another source of super spread occurs among health personnel who have to care for COVID patients for long periods of time, and inhale their respiratory secretions, without having appropriate protective equipment. Surgeons and other professionals have to attend the public: unknown people who may be carriers of the virus; therefore, are exposed to contagion. The main preventive protection that will help us reduce the viral load is: the widespread use of masks, eye protection, distancing, hand hygiene and sanitation of the environment. Even though there is a lack of evidence regarding their effectiveness, these should be used for precaution and must be compulsory and universal.

How to cite: Cuenca-Pardo J, Ramos-Gallardo G, Vélez-Benítez E, Álvarez-Díaz CJ, Bucio-Duarte J, IribarrenMoreno $\mathrm{R}$ et al. The importance of reducing the viral load to diminish the risk of COVID-19 spread. Cir Plast. 2020; 30 (2): 98-112. https://dx.doi.org/10.35366/i97674

\section{RESUMEN}

Realizamos una revisión sistemática sobre la importancia de disminuir la carga viral como una estrategia para reducir el riesgo de contagio o para minimizar la severidad de la enfermedad. Seleccionamos 113 publicaciones, analizamos los conceptos teóricos y realizamos las recomendaciones con la mejor evidencia médica disponible. La carga viral está relacionada con la tasa de ataque y severidad del COVID-19. Se ha reconocido que la producción de aerosoles es la principal fuente de contagio entre el personal sanitario. El riesgo de contagio es más alto en espacios cerrados y mal ventilados donde se convive con varias personas por mucho tiempo sin el debido distanciamiento y sin protección. La tasa de contagio es mayor a $80 \%$ y la mortalidad es muy alta. Otra fuente de contagio alto se da entre el personal sanitario que tiene que atender pacientes COVID por largos períodos de tiempo, y aspiran sus secreciones respiratorias sin contar con el equipo de protección adecuado. Los cirujanos y otros profesionales tienen que atender al público: personas desconocidas que pueden ser portadoras del virus, por lo que están expuestos al contagio. Los principales cuidados preventivos que ayudarán a disminuir la carga viral son: el uso generalizado de mascarillas, protección ocular, distanciamiento, higiene de las manos y desinfección del ambiente. Aunque faltan evidencias de su efectividad, estos cuidados deben aplicarse por precaución y ser obligatorios y universales. 


\section{OBJECTIVE}

$\mathrm{T}$ The COVID-19 pandemic will linger for a long time. Despite the risk of infection, we have returned to our activities, which must be done in a responsible and safe way. Some actions, carried out without adequate care will increase the risk of contagion. The objective of this work is to elaborate safety recommendations for plastic surgeons, which can also be used by other professionals who have to serve the general public and who are exposed to contagion by COVID-19. In order to reduce the viral load and, by doing so, reduce the risk of contagion or acquiring the disease, whether in its mild or asymptomatic form. The recommendations are based on the best available medical evidence and under the principle of precaution.

\section{METHODOLOGY}

We carried out a systematic review in Spanish and English, in the following information sites: PubMed, Embase, Cochrane, Medline, Fisterra, Medigraphic and Scholar Google. The keywords that we used in Spanish were: SARS-CoV-2, COVID-19 Viral load, contagion, prophylactic care, face masks, face respirators, distancing, eye protection, personal protective equipment, hand washing and environmental sanitation. We made basic questions related to the topic, we searched for the best available medical evidence to answer each question and we reached a consensus of a group of experienced surgeons. With the data obtained, we provided preventive recommendations for health personnel and patients and some infographics as quick, simple guides, but with enough information to allow the surgeon to reduce the viral load and reduce the risk of contagion.

\section{FINDINGS}

In PubMed we found 6,334 publications on viral load and COVID-19 and in Scholar Google: 23,700. We selected 113 articles that answered the questions we asked. We found 3 meta-analyzes (level of evidence I), 4 systematic reviews (level of evidence I and II), 2 prospective cohort studies (level of evidence II), 2 case reports (level of evidence
IV), 3 guidelines or medical manuals (level of evidence IV) and 99 simple reviews or opinions (level of evidence V). One of the publications was carried out by the Cochrane group.

\section{What is viral load and what is the use of quantifying it?}

The amount of viral particles in the plasma and patient's respiratory secretions or excreta have been called viral load. It is calculated by estimating the amount of viral particles in body fluids. ${ }^{1}$ The quantification of the viral load is very useful to evaluate the severity of the infection, to predict the evolution of viral infections and their relapses. It helps to assess the result of the treatment, to determine if the load increases or remains, or if the treatment has not been effective. ${ }^{2}$ Quantification can be performed by different means. The simplest and most accessible is by quantitative PCR, which allows the detection of minimal viral loads in the blood and is more sensitive than qualitative PCR taken from exudate in the pharynx. The qualitative PCR test detects over 200 virus copies per milliliter, the quantitative one detects 20 virus copies per milliliter; hence, it is 10 times more sensitive. ${ }^{1-3}$

\section{What is the relationship between viral load and severity of COVID-19?}

There is evidence that SARS-CoV-2 can be easily transmissible in an early stage of infection and in asymptomatic patients, which suggests a high viral load at this stage. Asymptomatic cases are more frequent in children. ${ }^{4-6}$

In a study, determination of viral load in sputum and feces was performed in 96 patients, where the maximum viral spread was found between 10 and 12 days and the duration was 18 days. The most severe cases had a higher viral load. In samples from the upper respiratory tract, a higher load was found in the initial stages of the disease. In the lower tract samples, numbers were high up to 14 days. In feces, the time span was longer than in the respiratory tract. Feces can be an important vector of contagion, the importance of managing feces to avoid contagion is emphasized. In the patients' plasma, the virus was found in up to $59 \%$ of the cases. The load 
was high even after the virus was no longer found in the respiratory tract. The virus was rarely found in urine. The application of steroids was related to a longer time of viral presence. Duration is longer in men than in women; so, the effect of hormones could be related. In patients over 60 years old, the permanence of the virus is longer, probably due to an immune deficit, characteristic of that age and due to higher levels of angiotensin-converting enzyme 2 in the alveoli, which is supposed to be a receptor for the different coronavirus. ${ }^{7}$

In recent studies, it was found that viral loads in severe cases were up to 60 times higher than in mild cases. ${ }^{2}$ In the group of asymptomatic individuals, the average contagion time was 19 days, less than the symptomatic group $(\mathrm{p}=$ 0.02 ). The IgG of asymptomatic patients was 3.4 vs 20.5 in the symptomatic group $(p=0.005)$. Cytokines were lower in asymptomatic patients. ${ }^{8}$

During the course of infection, the virus has been identified in respiratory tract samples 1 to 2 days before symptoms appear and persists up to 2 weeks in severe cases. ${ }^{9}$ Viral RNA shedding has also been detected in feces, pharyngeal exudate, blood, plasma, saliva, and urine, from 5 days on after the onset of symptoms and up to 4 to 5 weeks. ${ }^{7,9-13}$

Elimination of viral RNA is not equivalent to infectivity, but rather to the time that affected people continues to release viral particles. ${ }^{2}$

\section{How do we get it?}

A source of contagion of COVID-19 is by being close a symptomatic patient and in so coexisting without proper care; however, the most frequent cause is being with asymptomatic or pre-symptomatic people; since the disease is not obvious, there is a tendency to greater neglect with a greater risk. 5,13-19

It is not known for sure how many viruses it takes for someone to become infected. Recent studies offer some clues. Results from a research recently published in Nature, scientists affirm that they could not cultivate the coronavirus alive if the swab or sputum of a patient contained less than one million copies of viral RNA; therefore, a higher quantity is necessary to be infectious; however, the virus is highly contagious under suitable conditions in the environment and a susceptible host is required. Ten percent of positive cases infect $80 \%$ of new cases; that is, one patient infects 8 people. The attack rate is highly variable and has yet to be defined; some patients infect many, while others do not..$^{8-11}$

The proportion of asymptomatic people is a useful number to measure the true load of the disease and to interpret estimates of the potential for transmission better. ${ }^{1}$ This proportion varies widely among infectious diseases, from $8 \%$ for measles, $32 \%$ for coronavirus infections, up to $90-95 \%$ for polio. ${ }^{5-7}$ It is estimated that the percentage of asymptomatic individuals for SARS-CoV-2 should be greater than $80 \%{ }^{9-12}$

It is reported that transmission can be direct being in close contact, less than 1 meter with an infected patient producing small respiratory specks with a high viral load. in these circumstances, the particles are inhaled and deposited on the mucous. Another means is indirect transmission by fomites: the drops expelled by patients, deposited on surfaces or objects, from hours to days, depending on the material. When a person touches these fomites and then touches his or her face, he/she risks being infected. Another means of transmission is by air. Some actions can produce aerosols, with droplets with a diameter $<5 \mu \mathrm{m}$, which can remain in the air for long periods of time and reach people more than one meter away. Some aerosol generating procedures include: nebulizing with medication, endotracheal intubation, open suctioning, bronchoscopy, manual ventilation before intubation, turning the patient to the prone position, disconnecting the patient from a ventilator, non-invasive positive pressure ventilation, tracheostomy management, cardiopulmonary resuscitation, sputum induction techniques. ${ }^{19-25}$

\section{Smoke from surgical procedures}

Surgeons and operating room personnel are constantly exposed to smoke generated by the thermal destruction of tissues. The smoke generated represents a chemical and biological hazard: $1 \mathrm{~g}$ of flared tissue is equivalent to 6 cigarettes. ${ }^{26}$ Abdominoplasty is the plastic surgery procedure that generates the most particles: up to 3,900 particles $/ \mathrm{cm}^{3}$ can be 
produced, while in a hip replacement $400 / \mathrm{cm}^{3}$ are produced; a large amount is also produced during breast reduction surgery. ${ }^{27}$ Hepatitis and HIV viruses have been found in surgical smoke. ${ }^{28,29}$ The size of the particles in the smoke range from 0.05 to more than 25 microns. The Hepatitis B virus measures 0.042 microns, ${ }^{27}$ the HIV virus measures 0.1 to 0.12 microns $^{27}$ and the coronavirus measures 0.1 to 0.16 microns. ${ }^{30}$ Face masks filter particles larger than 5 microns, being ineffective even when used correctly. ${ }^{29,31}$ The SARS-CoV-2 virus could be present in surgical smoke and be transmitted by inhalation. There are no documented cases concerning this means of transmission. The operating room staff must take this liability into consideration and be properly protected from the effect of smoke and avoid the formation of aerosols by reducing the use of energy generating devices. ${ }^{30-32}$

\section{What is the means of highest transmission of SARS-CoV-2 infection?}

Many researchers maintain that it is rare to get coronavirus by coming into contact with a contaminated surface, as well as during a fleeting encounter with people who are infected. Contact with a patient's respiratory droplets and their aerosol effect have been identified as the main mode of transmission of COVID-19. Droplets smaller than 5 microns can remain in the air for a long time and be inhaled and deposited in the pulmonary alveoli; while large drops fall to the ground and quickly dry up. Poor ventilation systems in closed spaces make the viruses suspended in the air recirculate increasing the risk of contagion. The most common circumstances for infections would be face-to-face encounters and interactions among people for long periods of time. ${ }^{19-22}$

\section{What is a super contagion?}

The COVID attack rate is higher in closed and poorly ventilated spaces, where one stays with several people for a long time, without due distancing and without protection. Most of the time, the fact that one of them is already sick with COVID is ignored; besides, those are places where people speak loudly or sing. It has been estimated that speaking out loud for a minute generates at least a thousand droplets with viral particles, which could stay up to 8 minutes in the air. This set of conditions has been called super contagion and has appeared in members of musical choirs in churches, in people who go to restaurants or travel by bus or participate in parties; with a contagion rate higher than $80 \%$ and a very high mortality; whereas, the percentage of contagion is very low: from 4 to $19 \%$ in relatives of COVID patients who have been isolated and have used personal protection care during the disease. ${ }^{19-22}$

Another source of super contagion occurs with healthcare personnel who have to attend COVID patients for long periods of time, inhale their respiratory secretions and who do not have appropriate personal protective equipment. The attack rate of COVID-19 among health personnel was very high at the beginning of the pandemic; however, with improved care and exhaustive use of PPE, cases were considerably reduced. ${ }^{20-22,33}$

\section{What is the risk of contagion in healthcare personnel?}

Health personnel who carry out their work without adequate protection, are 3 times at a higher risk of contagion and it increases up to 5 times more when they are first-line health staff, who care for patients with COVID.

The risk also increases in the black community, Asians or ethnic minorities and with underlynig health risk. ${ }^{33}$

\section{When should we consider that a person is a suspect case of disease?}

All patients should be considered suspect cases of disease, until the disease is ruled out. They must be treated with extreme security protocols. There are many asymptomatic or presymptomatic patients who are unknowingly spreading viruses and exposing other patients and healthcare personnel to the risk of infection. ${ }^{19-22,34-38}$

\section{How can we reduce the viral load?}

During the pandemic, activities that involve an interpersonal relationship require effective regulations to avoid the spread of COVID-19. 
Different health organizations and the consensus of various specialists have issued action protocols, in order to reduce infections. Work activities can be resumed if distinct mechanisms are implemented to prevent massive infections in the population, establishing strategies for viral containment, such as: to use face masks as a mandatory requirement, implement good ventilation systems, keep windows open, sanitize work rooms by physical or chemical means, reduce meetings in closed spaces, limit the use of public transport and elevators, prohibit hugs, handshakes and fist bumps, use plastic partitions walls between desks, keep a distance between workers of at least 1.8 meters and perform serial tests on personnel. ${ }^{39-41}$

\section{What is the importance of using face masks, distancing and eye protection to reduce infections?}

The widespread use of masks by the general population can serve to reduce community transmission of the coronavirus; since the excretion of respiratory droplets from infected individuals, who have not yet developed symptoms or who remain asymptomatic, is reduced. The use of masks in the community is indicated mainly in crowded places, closed spaces or when using public transport. The use of masks in the community should be considered as a complementary measure and not as a replacement for the other established preventive measures; such as: hand hygiene. ${ }^{42,43}$

The use of facial masks reduces the inoculum of the virus, which causes a milder and asymptomatic infection. It is useful for the population that has to stay in closed environments (for example: cruise ships, offices and work places). Asymptomatic infections can be detrimental for spread, but could actually be beneficial if they lead to higher rates of controlled exposure, without the unacceptable consequences of serious illness, which could lead to increased immunity in the community, with slower dissemination. Some masks have a viral containment effect or decrease its flow with a lower virus load, without reaching the LD50. There is a marked increase in mild or asymptomatic infection in populations that have opted for the generalized use of face masks. ${ }^{44}$
During patients' breathing or coughing or sneezing, particles of different sizes are expelled. Those that measure between 60 to 100 microns, fall to the floor. The smallest respiratory droplets form aerosols that contain large amounts of particles smaller than 5 microns; can reach distances between 7 and 8 meters and remain in the air for a long time. Being so small, they can be inhaled and deposited in the pulmonary alveoli, producing the disease. This mechanism explains one of the mechanisms of super contagion. The use of surgical masks is not enough to contain the virus. The use of respirators with a viral containment filter is required. Respirators can contain up to $97 \%$ of aerosol particles and reduce the risk of contagion. To prevent shortages, the World Health Organization and the United States Centers for Disease Control and Prevention (CDC) recommend that the public wear cloth masks and leave surgical masks and N95 masks or similar ones for the exclusive use of healthcare personnel. ${ }^{45-53}$

In the current COVID pandemic, contradictory advice has been given on care to prevent contagion. The biggest controversies are with the use of masks by the community and distancing. Masks have been used for decades for infection prevention, at present facing challenges amid scarcity and ignorance. Recommendations should be based on the best evidence available, many of them stem from other respiratory viral infections, but a comprehensive review of information on SARSCoV-2 is not accessible. ${ }^{54-72}$

Surgical masks. A surgical mask is defined as a disposable device that is intended to create a physical barrier between the user's mouth and nose and possible contaminants in the immediate environment. These devices are intended to protect the user against splashes of bodily fluids generated during medical care procedures, and do not provide any type of respiratory protection, since they do not create a seal on the user's face. ${ }^{67-73}$

These devices are regulated by the Food and Drug Administration (FDA) and by the different ASTM standards (F2100, F2101, F2299, and F1862) in the United States of North America. These rules determine the quality and efficiency of masks and require performance evaluations 
of the following parameters: fluid resistance, bacterial and particulate filtration efficiency, flammability and biocompatibility. Bacterial Filtration Efficiency is performed with a test aerosol of approximately $3.0 \mu \mathrm{m} \pm 0.3 \mu \mathrm{m}$, and is commonly confused with the particle filtration efficiency with which respiratory protection equipment is approved. ${ }^{74}$

Cloth masks. To avoids the shortage of surgical masks or the N95, the CDC (Centers of Disease Control and Prevention of United States of America) and the $\mathrm{WHO}$ have recommended cloth masks for use by the general public. The cloth mask catches the droplets that measure between 5 and 10 microns, which are released when the person wearing it: talks, coughs, or sneezes. When it is widely used in public places, they can help reduce the transmission of the virus. Countries that have accepted the use of masks, along with other measures; such as: screening tests, isolation, and physical distancing early in the course of the pandemic, have been successful in reducing the transmission of the virus. They can be made from plain materials, such as: tightly spun cotton sheets. It is easy to find instructions on the Internet to make them; cloth masks should be multi-layered. The CDC website includes instructions for making cloth masks. ${ }^{42-45,65,66}$

Respiratory protection equipment (respirators). A respirator is defined as personal protective equipment that purifies or supplies air to protect the user's respiratory tract from contaminants found in the work environment. Respirators can be classified as: negative or positive pressure air purifiers and air supplied with positive or negative pressure line systems. These devices are designed to provide protection against any pollutant dispersed in the environment, provided they have been selected according to the danger present in the environment, and on condition that the user uses them correctly and consistently during the entire time that he/she remains in the workplace. ${ }^{67-78}$

Health authorities worldwide suggest the use of N95 respirators or their equivalents for health care professionals who are in contact with people who have been confirmed with the SARS-CoV-2 virus (COVID-19), especially in those procedures in which the generation of aerosols is produced. It has been recommended to dispose of respirators, once their life span is over, normally a working day. ${ }^{65-78}$

In the United States of America, the National Institute for Occupational Safety and Health (NIOSH) through standard 42 CFR 84 established the guidelines for the approval of respirators. According to this standard, NIOSH classifies particulate respirators in different classes, according to the type of filtering medium, and filtration efficiency (Tables 1 and 2). ${ }^{67-78}$

Respiratory protective equipment can be decontaminated by some methods approved by the FDA. This authorization is valid only during the declaration of sanitary emergency. For a decontamination method to be approved by the FDA, the following conditions should be met: ${ }^{78}$

- To inactivate the SARS-CoV-2 virus effectively.

- Not to damage the filter medium or any element of the respirator (nose clip, adjusting bands).

- Not to alter the fit provided by a disposable respirator.

- That the selected method does not represent a risk to the user of respirators.

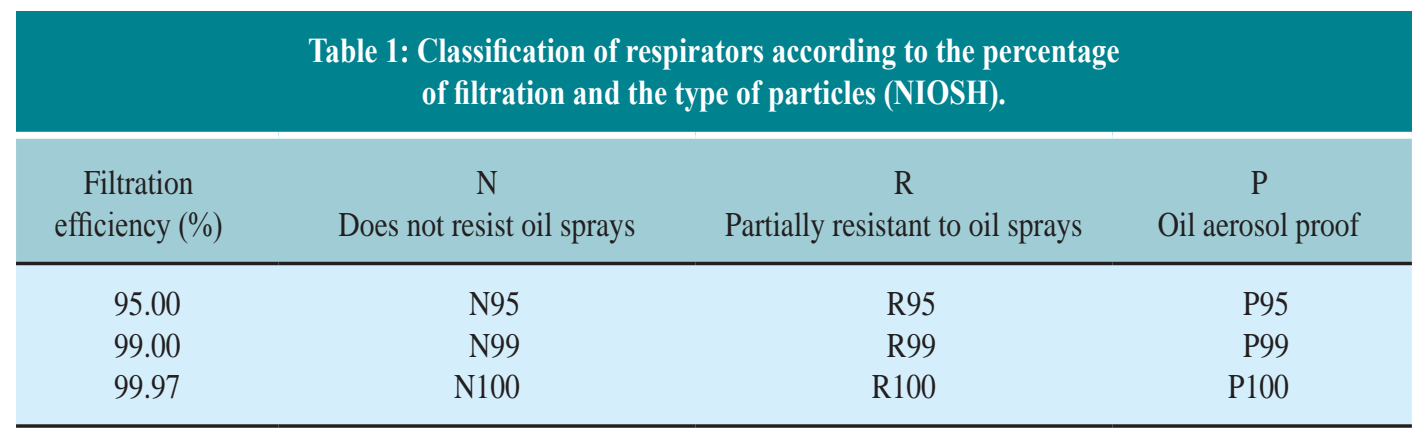




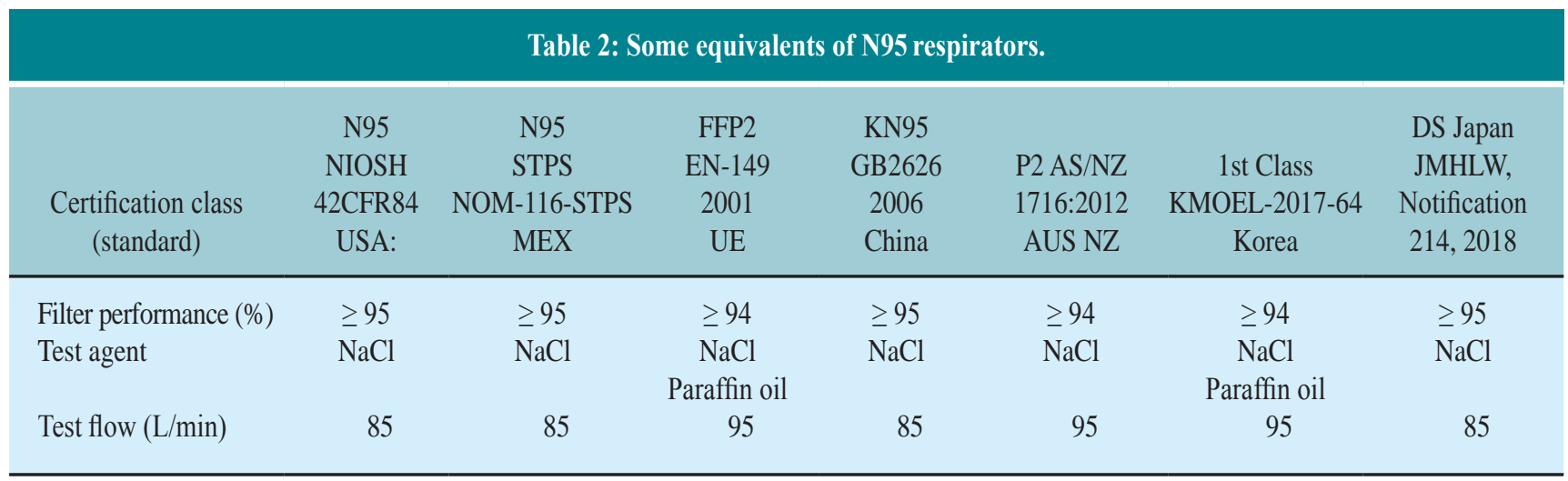

N95 masks. They are a type of respirator that offers more protection than a surgical mask because they can filter both large and small particles. As its name implies, the mask is designed to block $95 \%$ of small particles. Some N95 masks have valves that make it easier to breathe through them, as the valve releases unfiltered air. This type of mask does not prevent the person wearing it from transmitting the virus. For this reason, some places prohibit wearing them. Like surgical masks, N95s are intended to be disposable, but researchers are carrying out tests to find ways to disinfect the masks so they can be reused. ${ }^{65,66}$

In a meta analysis, they found that virus transmission was lower when the physical distance was larger than 1 meter; the risk decreases 2.02 times for each extra meter of distance $(p=0.041)$. NK95 or similar masks reduce the risk of infection by $14.3 \%$ compared to surgical masks $(p=0.09)$. Eye protection was also associated with less infection (10.6\%); robust randomized trials are needed. In the light of inconsistent guidelines from various organizations based on limited information, the findings provide some clarification. ${ }^{65,66}$

\section{What is the importance of hand hygiene to prevent COVID-19?}

The SARS-CoV-2 virus is an encapsulated virus, with a membrane made up of lipids and glycoproteins. The outer layer allows them to identify and bind to receptor sites on the host cell membrane, to fuse with it and facilitate the entry to the cell, where it will reproduce.
Encapsulated viruses are less stable and highly susceptible to soap action. ${ }^{53-66,79-85}$

Hand hygiene is considered one of the most effective means to avoid the spread of germs and to prevent the spread of COVID-19, especially after having been in public spaces or means of transport and having touched people and/or surfaces or objects, or after blowing one's nose, coughing, or sneezing. Organizations such as WHO, PAHO and the CDC recommend frequent hand washing with soap and water; or, if this is not possible, using an alcohol based hand sanitizer. ${ }^{53-66,79-85}$

Using soap to wash your hands is more effective than using plain water because the surfactants in soap remove dirt and microorganisms from the skin. In addition to this, it is considered that people tend to scrub their hands more thoroughly when using soap, which eliminates germs. Clean running water should be used for hand washing, as hands can become contaminated again if we use stagnant or recycled water. The CDC does not recommend the use of germicidal soaps, as they do not offer greater benefit. ${ }^{53-66,79-85}$

Hygienic treatment of the hands with antiseptics or alcohol based disinfectants at a concentration of 60 to $85 \%$ provides an additional benefit to washing with soap and running water and can be very useful in situations where there is no running water and soap. These alcohol products can quickly reduce bacteria, fungi, yeast, mycobacteria, and viruses. It is important to be aware that if the hands are dirty or greasy, they should be washed with soap and water before using the 
antiseptic, as dirt can significantly reduce the action of the product. ${ }^{53-66,79-85}$

\section{What is the importance of cleaning (sanitizing) and disinfection of public spaces?}

Cleaning and disinfection are an important part of reopening public spaces and require meticulous planning. Frequent cleaning with soap and water will reduce the amount of virus on surfaces and objects that people often touch; disinfection will help their elimination. These precautions reduce the risk of exposure. Viruses that are found on surfaces and objects die naturally after hours or days; heat, ventilation and sunlight greatly reduce survival time. ${ }^{53-66,79-85}$

Evaluating the workplace, school, home or company is recommended to determine what types of surfaces and materials are present in that area. Most surfaces and objects will only need regular routine cleaning. Frequently touched surfaces and objects; such as: light switches and door handles should be cleaned and then disinfected to reduce the presence of germs on surfaces and objects further. If your workplace, school or business has been unoccupied for 7 days or more, it will only take a normal routine cleaning to reopen the area. This is because the virus that causes COVID-19 has not been shown to survive on surfaces longer than this time. ${ }^{53-66,79-85}$

Disinfectants help eliminate germs from surfaces. They are not a substitute for soap. If sanitizers are scarce, 1/3 cup of chlorine bleach diluted in 1 gallon of water or $70 \%$ alcohol solutions can be used. Chlorine bleach solutions will be effective for disinfecting for up to 24 hours. Store and use disinfectants responsibly and properly, as indicated on the label. Do not waste or stockpile disinfectants or other supplies. This can lead to a shortage of products that other people need to use in critical situations. Do not mix chlorine bleach with other cleaning and sanitizing products, which can cause very dangerous fumes. Keep all disinfectants out of children's reach. ${ }^{53-66,79-85}$

Some contaminated items (fomites) can be moved or removed, to reduce handling or contact. Soft, porous materials, such as: carpets and seats can be removed or put away so they don't have to be cleaned and disinfected. Carpets and rugs are not easy to disinfect. If you need to keep them, they should be washed in the washing machine, following the instructions on the item's label and with the highest possible water temperature setting, dry with heat or expose them to sunlight. . $3-66,79-85^{-}$

Outdoor areas generally require normal routine cleaning and do not need to be disinfected. Spraying disinfectant on sidewalks and parks is not an efficient use of disinfectants and has not been proven to reduce the public's risk of contracting COVID-19. There is no evidence that the virus that causes COVID-19 can spread directly to humans from the water in swimming pools, hot tubs or spas, or water games areas. Proper use, maintenance, and disinfection (for example, with chlorine or bromine) should kill the virus that causes COVID-19; however, the situation is different in outdoor areas that are less frequently maintained, including playgrounds or other facilities located in local, state, or national parks. ${ }^{53-66,79-85}$

\section{Is the use of ultraviolet light and ozone useful to eliminate the COVID-19 virus?}

The use of short wavelength ultraviolet light can be useful for disinfecting work areas, applied prior to the beginning of activities. ${ }^{40,41,85,86}$

At UC Santa Barbara's Solid State Lighting and Power Electronics Center (SSLEEC), some researchers are developing ultraviolet LEDs that have the ability to decontaminate surfaces and potentially air and water, that have been in contact with the SARS-CoV virus. They have used it in the disinfection of personal protective equipment, surfaces and floors. Ultraviolet light for disinfection purposes had already been used for a long time, although demonstrating its effectiveness in the SARS-CoV-2 disinfection has not been completed. Its use for these purposes is very promising. An SSLEEC member company, Seoul Semiconductor, reported 99.9\% sterilization of coronavirus (COVID-19) in 30 seconds with its UV LED products. Not all UV wavelengths are the same; one comes from the sun; that which is required to purify air and water, and that to inactivate microbes can only be generated 
through man-made processes. UVC light in the range of 260-285 nm used for disinfection is harmful to human skin, so its application must be done when no one is present at the time of disinfection. Conventional germicidal UVC light (wavelength $254 \mathrm{~nm}$ ) can be used to disinfect unoccupied spaces, such as: empty hospital rooms or empty subway cars, but direct exposure to these conventional UV lamps is not possible in busy public spaces, as this could be a health hazard. To disinfect occupied indoor areas continuously and safely, researchers at Columbia University Irving Medical Center have been investigating distant UVC light (wavelength $222 \mathrm{~nm}$ ). Distany UVC light cannot penetrate the tear layer of the eye or the outer layer of dead skin; consequently it cannot reach or damage the living cells of the body. The researchers had previously shown that distant ultraviolet light can kill airborne flu viruses safely. The World Health Organization warns against the use of ultraviolet disinfection lamps to disinfect hands or other areas of the skin; even brief exposure to UV-C light can cause burns and eye injury. There are great technological advances in ultraviolet light generating devices. Mercury vapor lamps have been used, LED systems and alignment of various metals. The time will come when deeper, safer and more economical light can be obtained. Even with its limitations, the current use of ultraviolet light is safe and economical compared to other means of disinfection. More than $99.9 \%$ of seasonal coronaviruses in airborne droplets died when exposed to a specific wavelength of ultraviolet light that is safe to be used around humans, a new study at Irving Medical Center found. It could greatly reduce the level of virus in the air in humanoccupied indoor environments. That study extends its research to seasonal coronaviruses, which are structurally similar to the SARSCoV-2 virus that causes COVID-19. ${ }^{40,86}$ During the course of the investigation, the researchers used a nebulizer device to disperse two common coronaviruses. The aerosols containing coronavirus were flowed through the air in front of a distant UVC lamp. After exposure to distant UVC light, the researchers tested to see how many of the viruses were still alive. They found that more than 99.9\% of the exposed virus had been killed by very low exposure to distant ultraviolet light. Based on their results, these examiners estimate that continued exposure to distant ultraviolet light at the current regulatory limit would kill 90\% of airborne viruses in about 8 minutes, 95\% in about 11 minutes, $99 \%$ in approximately 16 minutes and $99.9 \%$ in about 25 minutes. The sensitivity of coronaviruses to distant ultraviolet light suggests that it may be feasible and safe to use distant ultraviolet overhead lamps in public places, busy indoors to reduce the risk of person-to-person transmission of coronavirus noticeably, as well as other viruses; such as: influenza. In a separate ongoing study, researchers are testing the effectiveness of distant UVC light against SARS-CoV-2 in the air. Preliminary data suggests that distant UVC light is successful in killing SARS-CoV-2. Since SARS-CoV-2 is transmitted largely through droplets and aerosols that are coughed and sneezed into the air, it is important to have a tool that can safely inactivate the virus while airborne, especially when there are people nearby. Distant UV light is safe in busy spaces like hospitals, buses, airplanes, trains, train stations, schools, restaurants, offices, theaters, gyms and anywhere people gather indoors. Distant ultraviolet light could be used in combination with other measures; such as: wearing masks and washing hands, to limit the transmission of SARS-CoV-2 and other viruses. ${ }^{40,41,85,86}$

Disposal of personal protective equipment is highly recommended; if it needs to be reused, it can be disinfected with ultraviolet light and ozone. ${ }^{40,85-89}$ Ozone has been used for disinfection and to reduce the risk of infection by aerosols containing viruses; such as: COVID-19 It is a natural gas composed of three oxygen atoms $\left(\mathrm{O}_{3}\right)$, created by solar radiation it is used for protection against harmful effects of UV rays. It is inorganic, colorless, dry, with a strong and unpleasant odor, explosive, and soluble in pure water. It is the strongest natural oxidant in nature, with a short half life of 140 min at $0{ }^{\circ} \mathrm{C}, 40$ minutes at $20^{\circ} \mathrm{C}$ and 25 minutes at $30^{\circ} \mathrm{C}$. It is produced by generators from pure oxygen as it passes through a high voltage gradient. ${ }^{40,82-90}$ In organisms it is a part of oxygen free radicals and it participates in the 
modulation of oxidative stress, with induction of pro-inflammatory cytokines. It participates in the modulation of the immune system, improves the phagocytic activity of neutrophils and the function of erythrocytes. ${ }^{89-106}$

The peroxidation produced by ozone damages the viral cell wall, alters the reproductive cycle, inhibits its growth, and interrupts the contact of the virus with the cell. It is involved in the oxidation of glycoproteins and glycolipids, blocking the enzymatic function of the virus. The coronavirus has a coating rich in cysteine, which must remain intact for viral activity; cysteine contains thiol or sulfhydryl groups (-SH), essential for cell fusion and entry; being vulnerable to ozone, with long-term antiviral effects. The effectiveness of ozone therapy is due to the decrease in the viral load. $5,88,89$ Lipid-coated encapsulated viruses are the most sensitive, and coronavirus is one of them. ${ }^{3,6}$ An exposure for 30 minutes at doses of 0.03 to $10 \mathrm{ppm}$ inactivates the viruses contained in the aerosols. It has been used to inactivate several viruses; such as: hepatitis A, poliovirus, smallpox, HIV-1, cytomegalovirus, and Ebola. ${ }^{87-91}$ The concentration for viral inactivation is not cytotoxic, ${ }^{90}$ it disinfects spaces that are hard to reach. The extra benefit of this gas is its prompt transformation into molecular oxygen without toxic residues. ${ }^{93-106}$

To care for a patient or the general public, what protective equipment should be used according to the degree of contagion risk?

There are several guides for the use of personal protective equipment (PPE) and preventive care; the recommendations are made according to the risk and use of 4 grades (see infographic). ${ }^{107-109}$

Low risk. Workers who do not have contact with people known or suspected of being infected with SARS-CoV-2. They can maintain a distance greater than 1.5 meters. They have minimal occupational contact with public and/ or with their co-workers. Recommendations: see infographic.

Moderate risk. They are workers with a medium exposure risk; have frequent and/or close contact; that is, within 1.5 meters, with unknown people who may have the disease; frequent contact with travelers returning from places where the pandemic has widespread transmission; contact with the general public (e.g. schools, high-density work environments, some high-volume retail environments). Recommendations: see infographic.

High risk of exposure. High risk of exposure jobs are those with high potential for exposure to known or suspected sources of COVID-19. Workers in this category include:

- Healthcare and support personnel (e.g. doctors, nurses, and other hospital personnel required to enter rooms) exposed to known or suspected COVID-19 patients. (Note: when such workers perform procedures, their level of exposure risk becomes very high).

- Medical transportation workers (e.g. ambulance operators) moving known or suspected COVID-19 patients in closed vehicles.

- Mortuary workers involved in preparing (for example: for burial or cremation) the bodies of people known to have, or suspected of having COVID-19, at the time of death.

Very high risk. Very high exposure risk jobs are those with high potential for exposure to known or suspected sources of COVID-19 during specific medical, post-mortem, or laboratory procedures. Workers in this category include:

- Healthcare workers (e.g. physicians, nurses, dentists, paramedics, emergency medical technicians) performing aerosol generating procedures (e.g. intubation, induction procedures, bronchoscopies, some procedures and tests, or invasive specimen collection) in known or suspected COVID-19 patients.

- Healthcare or laboratory personnel collecting or handling samples from known or suspected COVID-19 patients (for example: handling cultures from known or suspected COVID-19 patients.)

- Mortuary workers who perform autopsies, which generally involve aerosol generating 
procedures, on the bodies of people known to have, or suspected of having COVID-19, at the time of death.

\section{DISCUSSION}

There are a large number of publications regarding viral load and COVID-19; however, there are few studies with a level of evidence I or II that allow to issue care with a high level of recommendation; most are reviews that are simple or opinions. The theoretical concepts of this work consider recommendations with the best medical evidence. Such concepts will need to change or be adjusted once new evidence appears, forcing readers to remain up to date. We use the precautionary principle, which is a concept that supports the adoption of protective measures in the face ofreasonable grounds for suspicions that certain products, technologies or infections create a serious risk to public health. The recommendations that are given will be made without definitive scientific proof and the principle of therapeutic proportionality, which implies that preventive measures provide greater benefits and a very low or no risk, due to the use of these measures. In addition, these preventive recommendations are low cost, accessible, and easy to understand and apply. ${ }^{110-112}$

In daily clinical practice, plastic surgeons and other professionals have to serve the general public, people unknown to us, who may be carriers of the virus, so we are exposed to becoming infected with COVID-19. All patients should be considered positive to COVID-19 until the disease is ruled out through laboratory tests. The most frequent cause of contagion is asymptomatic or pre-symptomatic people; the disease not being apparent, there is a tendency to greater neglect at a higher risk. ${ }^{5,13-22,34-38} \mathrm{We}$ must perform our activities in a responsible and safe way; some practices not being scrupulous will increase the risk of contagion.

It has been recognized that the production of aerosols is the main source of contagion in health personnel. Aerosols are generated in different medical and surgical procedures. In the early stages of the pandemic, the percentage of health personnel who became infected was very high. Nowadays, they have better personal protective equipment and experience, which has made it possible to adopt preventive measures, achieving a considerable reduction in the number of infections. ${ }^{19-25,33}$

The COVID attack rate is higher in closed and poorly ventilated spaces, where people are with several persons for a long time, without due distancing and without protection. Most of the time, the fact that one of them is already sick with COVID is ignored. The contagion rate is higher than $80 \%$ and there is very high mortality. This type of spread has been called supercontagion. ${ }^{19-22}$ Another source of supercontagion occurs with healthcare personnel who have to attend COVID patients for long periods of time, inhale their respiratory secretions and do not have the appropriate personal protective equipment. ${ }^{20-22,33}$ The most common circumstances for infections would be face-to-face encounters and interactions with people for long periods. ${ }^{19-22}$

\section{CONCLUSIONS}

There is sufficient evidence to support the theory that by reducing the viral load, there is a lower probability of contagion and if infected, the disease is mild or asymptomatic. Reducing the viral load is imperative during our practice. The pillars of preventive care that will help us reduce the viral load are: the generalized use of masks, eye protection, distancing, hand hygiene and sanitation of the environment. Even when evidence is lacking, suspecting or confirming COVID, this attention should be applied under «the principle of precaution» in order to reduce community transmission of the coronavirus. All health authorities should opt for these preventive measures, as they are inexpensive, easy to apply and promise good results. ${ }^{42-44,55-85}$ It is important that the application of these regulations is mandatory and universal; (si es universal, ipor qué repetir para todos?) They are regulations for everyone and everyone must comply with them! $!^{39-41}$

\section{REFERENCES}

1. Franco AE, Serrano R, Gimeno A, De Juan J, Merino E, Jiménez del Cerro L et al. Estudio de carga viral y antigenemia como valores predictivos de recidiva de infección CMV en el trasplante renal. Nefrología 2007; 27 (2): 202-208. 
2. Liu Y, Yan LM, Wan L, Xiang TX, Le A, Liu JM et al. Viral dynamics in mild and severe cases of COVID-19. Lancet Infect Dis 2020; 20 (6): 656-657. doi: 10.1016/S1473-3099(20)30232-2.

3. PCR cuantitativa para la detección de la carga viral. Available in: https://www.empireo.es/ enfermedadestransmisionsexual/prueba-de-vih/ vih-cuantitativa/

4. Bai Y, Yao L, Wei T, Tian F, Jin DY, Chen L et al. Presumed asymptomatic carrier transmission of COVID-19. JAMA 2020; 323 (14): 1406-1407. doi: 10.1001/jama.2020.2565.

5. To KK, Tsang OT, Leung WS, Tam AR, Wu TC et al. Temporal profiles of viral load in posterior oropharyngeal saliva samples and serum antibody responses during infection by SARS-CoV-2: an observational cohort study. Lancet Infect Dis 2020; 20 (5): 565-574. doi: 10.1016/S1473-3099(20)30196-1.

6. Mizumoto K, Kagaya K, Zarebski A, Chowell G. Estimating the asymptomatic proportion of coronavirus disease 2019 (COVID-19) cases on board the Diamond Princess cruise ship, Yokohama, Japan, 2020. Euro Surveill 2020; 25 (10): 2000180. doi: 10.2807/1560-7917.ES.2020.25.10.2000180.

7. Zheng S, Fan J, Yu F, Feng B, Lou B, Zou Q et al. Viral load dynamics and disease severity in patients infected with SARS-CoV-2 in Zhejiang province, China, January-March 2020: retrospective cohort study. BMJ 2020; 369: m1443. doi: 10.1136/bmj. m1443.

8. Long QX, Tang XJ, Shi QL, Li Q, Deng HJ, Yuan J et al. Clinical and immunological assessment of asymptomatic SARS-CoV-2 infections. Nat Med 2020; 26 (8): 1200-1204. doi: 10.1038/s41591020-0965-6.

9. European Centre for Disease Prevention and Control (ECDC). Situation update worldwide [cited 20201 March]. Available from: https://www.ecdc.europa. eu/en/geographical-distribution-2019-ncov-cases.

10. Young BE, Ong SWX, Kalimuddin S, Low JG, Tan SY, Loh J et al. Epidemiologic features and clinical course of patients infected with SARS-CoV-2 in Singapore. JAMA 2020; 323 (15): 1488-1494. doi: 10.1001/ jama.2020.3204.

11. Chang L, Yan Y, Wang L. Coronavirus disease 2019: coronaviruses and blood safety. Transfus Med Rev 2020; 34 (2): 75-80.

12. Huang $C$, Wang $Y$, Li X, Ren L, Zhao J, Hu Y et al. Clinical features of patients infected with 2019 novel coronavirus in Wuhan, China. Lancet 2020; 395 (10223): 497-506.

13. Backer JA, Klinkenberg D, Wallinga J. Incubation period of 2019 novel coronavirus (2019-nCoV) infections among travellers from Wuhan, China, 2028 January 2020. Euro Surveill 2020; 25 (5): 2000062. doi: 10.2807/1560-7917.ES.2020.25.5.2000062.

14. Peng L, Liu J, Xu W, Luo Q, Deng K, Lin B et al. 2019 Novel Coronavirus can be detected in urine, blood, anal swabs and oropharyngeal swabs samples. medRxiv 2020. doi: https://doi. org/10.1101/2020.02.21.20026179

15. Nishiura H, Kobayashi T, Miyama T, Suzuki A, Jung $\mathrm{S}$, Hayashi $\mathrm{K}$ et al. Estimation of the asymptomatic ratio of novel coronavirus infections (COVID-19). Int J Infect Dis 2020; 94: 154-155. doi: 10.1016 / j.ijid.2020.03.020.

16. Wu Z, McGoogan J. Characteristics of and important lessons from the coronavirus disease 2019 (COVID-19) outbreak in china summary of a report of 72314 cases from the Chinese Center for Disease Control and Prevention. JAMA 2020; 323 (13):1239-1242. doi: 10.1001/jama.2020.2648.

17. Chen N, Zhou M, Dong X, Qu JM, Gong FY, Han Y et al. Epidemiological and clinical characteristics of 99 cases of 2019 novel coronavirus pneumonia in Wuhan, China: a descriptive study. Lancet 2020; 395: 507-513. doi: 10.1016/s0140-6736(20)30211-7.

18. Luo SH, Liu W, Liu ZJ, Zheng XY, Hong CX, Liu ZR et al. A confirmed asymptomatic carrier of 2019 novel coronavirus. Chin Med J (Engl) 2020; 133 (9): 11231125. doi: 10.1097/CM9.0000000000000798.

19. INFOBAE. ¿Cómo nos contagiamos de COVID-19? Julio 2020. Available in: https://www.infobae. com/america/mundo/2020/06/25/como-noscontagiamos-coronavirus-entre-los-expertos-haycada-vez-mas-consensos/.

20. El supercontagio en esta pandemia podría ser una buena noticia. Julio 2020. Available in: https://www. nationalgeographic.com.es/ciencia/supercontagioesta-pandemia-podria-ser-buena-noticia 15594.

21. Pérez Caballero J. Sobre el uso popular del término "súper propagador" del COVID-19. El Catoblepas 2020; 191: 33.

22. Enfermedad por Coronavirus, COVID-19. Actualización 3 de julio de 2020. Available in: https:// www.mscbs.gob.es/profesionales/saludPublica/ ccayes/alertasActual/nCov-China/documentos/ ITCoronavirus.pdf.

23. Edwards SP, Kasten S, Nelson C, Elner V, McKean E. Maxillofacial trauma management during COVID-19: multidisciplinary recommendations. Facial Plast Surg Aesthet Med 2020; 22 (3): 157-159. doi: 10.1089 / fpsam.2020.0158.

24. Givi B, Schiff BA, Chinn SB, Clayburgh D, lyer $N G$, Jalisi $S$ et al. Safety recommendations for evaluation and surgery of the head and neck during the COVID-19 pandemic. JAMA Otolaryngol Head Neck Surg 2020; 146 (6): 579-584. doi: 10.1001/ jamaoto.2020.0780.

25. Wang D, Hu B, Hu C, Zhu F, Liu X, Zhang J et al. Clinical characteristics of 138 hospitalized patients with 2019 novel coronavirus-infected pneumonia in Wuhan, China. JAMA 2020; 323 (11): 1061-1069. doi: 10.1001/jama.2020.1585.

26. Hill DS, O'Neill JK, Powell RJ, Oliver DW. Surgical smoke a health hazard in the operating theatre: a study to quantify exposure and a survey of the use of smoke extractor systems in UK plastic surgery units. J Plast Reconstr Aesthet Surg 2012; 65: 911916.

27. Ragde SF, Jorgensen RB, Foreland S. Characterization of exposure to ultrafine particles from surgical smoke by use of a fast mobility particle sizer. Ann Occup Hyg 2016; 60 (7): 860-874.

28. Kwak HD, Kim SH, Seo YS, Song KJ. Detecting hepatitis B virus in surgical smoke emitted during 
laparoscopic surgery. Occupy Environ Med 2016; 73: 857-863.

29. Vourtzoumis P, Alkhamesi N, Elnahas A. Operating during COVID-19: is there a risk of viral transmission from surgical smoke during surgery? Can J Surg 2020; 63 (3): E299-E301.

30. Zhu N, Zhang D, Wang W, Li X, Yang B. A novel coronavirus from patients with pneumonia in China 2019. N Engl J Med 2020; 382: 727-733. doi: 10.1056 / NEJMoa2001017.

31. Mowbray N, Ansell J, Warren N, Wall P, Torkington J. Is surgical smoke harmful to theater staff? A systematic review. Surg Endosc. 2013; 27 (9): 3100-3107.

32. Mowbray NG, Ansell J, Horwood J, Cornish J, Rizkallah P, Parker A et al. Safe management of surgical smoke in the age of COVID-19. $\mathrm{Br}$ J Surg 2020; 107 (11): 1406-1407. doi: 10.1002/ bjs. 11679 .

33. Nguyen LH, Drew DA, Graham MS, Joshi AD, Guo CG, Ma W et al. Risk of COVID-19 among front-line health-care workers and the general community: a prospective cohort study. Lancet Public Health. 2020; 5 (9): e475-e483. doi: 10.1016/S24682667(20)30164-X.

34. Stahel PF. How to risk-stratify elective surgery during the COVID-19 pandemic? Patient Saf Surg 2020; 14: 8. doi: 10.1186/s13037-020-00235-9.

35. McKay B, Calfas J, Ansari T. Coronavirus declared pandemic by World Health Organization. Wall St 2020.

36. Commins J. Surgeon general urges providers to consider stopping all elective surgeries - hospitals push back. Health Leaders 2020.

37. Evans M, Wilde MA. Hospitals push off surgeries to make room for coronavirus patients. Wall St J 2020

38. Martines J. UPMC shuns health experts' calls to cancel elective surgeries. Pittsburgh Tribune-Review 2020.

39. Barnes M, Sax PE. Challenges of "return to work" in an ongoing pandemic. New Engl J Med 2020; 383: 779-786. doi: 10.1056/NEJMsr2019953.

40. SaifAddin BK, Almogbel AS, Zollner CJ, Wu F, Bonef $\mathrm{B}$, Iza $\mathrm{M}$ et al. AIGaN deep ultraviolet light-emitting diodes grown on SiC substrates. ACS Photonics 2020; 7: 554-561. doi: 10.1021/acsphotonics.9b00600.

41. Ultraviolet LEDs prove effective in eliminating coronavirus from surfaces and, potentially, air and water. Science Daily. 2020. Available in: https://www. science daily.com/releases/2020/04/200414173251

42. Cochrane Iberoamérica. ¿Está justificado el uso generalizado de mascarillas para evitar la transmisión comunitaria del nuevo coronavirus? 19 de abril de 2020. Available in: https://es.cochrane. org/es/\%C2\%BFest\%C3\%A1-justificado-el-usogeneralizado-de-mascarillas-para-evitar-latransmisi\%C3\%B3n-comunitaria-del

43. Coronavirus: mascarillas y evidencias científicas. Urgencias y emergencias. Actualización 22 de junio de 2020. Available in: https://www. urgenciasyemergen.com/coronavirus-mascarillas-yevidencia-cientifica/

44. Gandhi M, Beyrer Ch, Goosby E. Masks do more than protect others during COVID-19: reducing the inoculum of SARS-CoV-2 to protect the wearer. J Gen Inter Med 2020. doi: 10.1007/s11606-020-06067-8.

45. Fennelly K. Particle size of infectious aerosols: implications for infection control. Lancet Resp Med 2020. doi: 10.1016/S2213-2600(20)30323-4.

46. Bourouiba L. Turbulent gas clouds and respiratory pathogen emissions: potential implications for reducing transmission of COVID-19. JAMA 2020. doi: 10.1001/jama.2020.4756.

47. Tang JW, Settles GS. Images in clinical medicine. Coughing and aerosols. N Engl J Med 2008; 359: e19.

48. Xie X, Li Y, Chwang AT, Ho PL, Seto WH. How far droplets can move in indoor environments-revisiting the Wells evaporation falling curve. Indoor Air 2007; 17: 211-225.

49. Bahl P, Doolan C, De Silva C, Chughtai AA, Bourouiba L, Macintyre CR. Airborne or droplet precautions for health workers treating COVID-19? J Infect Dis 2020. doi: 10.1093/infdis/jiaa189.

50. Lindsley WG, Noti JD, Blachere FM, Szalajda JV, Beezhold DH. Efficacy of face shields against cough aerosol droplets from a cough simulator. J Occup Environ Hyg 2014; 11: 509-518.

51. Dharmadhikari AS, Mphahlele M, Stoltz A et al. Surgical face masks worn by patients with multidrug-resistant tuberculosis: impact on infectivity of air on a hospital ward. Am J Resp Crit Care Med 2012; 185: 1104-1109.

52. Wood ME, Stockwell RE, Johnson GR et al. Face masks and cough etiquette reduce the cough aerosol concentration of Pseudomonas aeruginosa in people with cystic fibrosis. Am J Resp Crit Care Med 2018; 197: 348-355.

53. Prather KA, Wang CC, Schooley RT. Reducing transmission of SARS-CoV-2. Science 2020; 368: 1422-1424.

54. Worldometer. COVID-19 coronavirus pandemic. 2020. Available in: https://www.worldometers.info/ coronavirus/

55. Guo ZD, Wang ZY, Zhang SF et al. Aerosol and surface distribution of severe acute respiratory syndrome coronavirus 2 in hospital wards, Wuhan, China, 2020. Emerg Infect Dis 2020. doi: 10.3201/ eid2607.200885.

56. Chia PY, Coleman KK, Tan YK, Ong SWX, Gum $M$, Lau SK et al. Detection of air and surface contamination by SARS-CoV-2 in hospital rooms of infected patients. Nat Commun 2020; 11 (1): 2800. doi: 10.1038/s41467-020-16670-2.

57. Santarpia JL, Rivera DN, Herrera V et al. Transmission potential of SARS-CoV-2 in viral shedding observed at the University of Nebraska Medical Center. medRxiv 2020. doi: 10.1101/2020.03.23.20039446.

58. Cheng V, Wong SC, Chen J et al. Escalating infection control response to the rapidly evolving epidemiology of the coronavirus disease 2019 (COVID-19) due to SARS-CoV-2 in Hong Kong. Infect Control Hosp Epidemiol 2020; 41: 493-498.

59. Wong SCY, Kwong RTS, Wu TC et al. Risk of nosocomial transmission of coronavirus disease 2019: an experience in a general ward setting in Hong Kong. J Hosp Infect 2020; 105: 119-127.

60. Faridi S, Niazi S, Sadeghi K et al. A field indoor air measurement of SARS-CoV-2 in the patient rooms 
of the largest hospital in Iran. Sci Total Environ 2020; 725: 138401.

61. Ong SWX, Tan YK, Chia PY et al. Air, surface environmental, and personal protective equipment contamination by severe acute respiratory syndrome coronavirus 2 (SARS-CoV-2) from a symptomatic patient. JAMA 2020; 323: 1610-1612.

62. Qualls N, Levitt A, Kanade N et al. Community mitigation guidelines to prevent pandemic influenza: United States, 2017. MMWR Recomm Rep 2017; 66: 1-34.

63. Feng S, Shen C, Xia N, Song W, Fan M, Cowling BJ. Rational use of face masks in the COVID-19 pandemic. Lancet Resp Med 2020; 8: 434-436.

64. Maclntyre R, Chughtai A, Tham CD, Seale H. COVID-19: should cloth masks be used by healthcare workers as a last resort? BMJ 2020. Available in: https://blogs.bmj.com/bmj/2020/04/09/covid-19should-cloth-masks-be-used-by-healthcare-workersas-a-last-resort/

65. Jefferson $\mathrm{T}$, Jones M, Al Ansari LA, Bawazeer G, Beller E, Clark J et al. Physical interventions to interrupt or reduce the spread of respiratory viruses. Part 1 - Face masks, eye protection and person distancing: systematic review and meta-analysis. medRxiv 2020. doi: https://doi.org/10.1101/2020. 03.30.20047217.

66. Chu DK, Akl EA, Duda S, Solo K, Yaacoub S, Schünemann HJ; COVID-19 Systematic Urgent Review Group Effort (SURGE) study authors. Physical distancing, face masks, and eye protection to prevent person-to-person transmission of SARS-CoV-2 and COVID-19: a systematic review and meta-analysis. Lancet 2020; 395 (10242): 1973-1987. doi: 10.1016/S0140-6736(20)31142-9.

67. Howard J, Huang A, Li Z, Tufekci Z, Zdimal V, van der Westhuizen $\mathrm{H}$ et al. Face masks against COVID-19: an evidence review. Preprints 2020; 2020040203 doi: 10.20944/preprints202004.0203.v1.

68. Brainard JS, Jones N, Lake I, Hooper L, Hunter P. Facemasks and similar barriers to prevent respiratory illness such as COVID-19: A rapid systematic review. medRxiv 2020. doi: 10.1101/2020.04.01.20049528.

69. Greenhalgh T, Schmid MB, Czypionka T, Bassler $\mathrm{D}$, Gruer L. Face masks for the public during the covid-19 crisis. Br Med J 2020; 369: m1435. doi: 10.1136/bmj.m1435.

70. WHO Health Emergencies Preparedness and Response Team. Advice on the use of masks in the context of COVID-19. 2020. WHO reference number WHO/2019-nCov/IPC Masks/2020.3.

71. WHO. Non-pharmaceutical public health measures for mitigating the risk and impact of epidemic and pandemic influenza. 2019. ISBN: 978-92-4-151683-9.

72. Recommendation Regarding the Use of Cloth Face Coverings, Especially in Areas of Significant Community-Based Transmission. National Center for Immunization and Respiratory Diseases (NCIRD), Division of Viral Diseases. 2020. Available in: https:// www.cdc.gov/coronavirus/2019-ncov/prev

73. https://www.fda.gov/medical-devices/personalprotective-equipment-infection-control/n95respirators-surgical-masks-and-face-masks
74. https://www.nelsonlabs.com/testing/bacterial-viralfiltration-efficiency-bfe-vfe

75. http://www.dof.gob.mx/normasOficiales/3926/stps3/ stps3.htm

76. https://multimedia.3m.com/mws/media/1791500O/ comparison-ffp2-kn95-n95-filtering-facepiecerespirator-classes-tb.pdf

77. https://www.cdc.gov/coronavirus/2019-ncov/hcp/ ppe-strategy/index.html

78. https://www.fda.gov/emergency-preparednessand-response/mcm-legal-regulatory-and-policyframework/emergency-use-authorization\#covidppe

79. https://higieneambiental.com/aire-agua-y-legionella/ higiene-de-las-manos-para-prevenir-el-covid-19. 20 de marzo de 2020

80. https://www.who.int/es/emergencies/diseases/novelcoronavirus-2019/advice-for-public. https://www. paho.org/es/eventos/agua-saneamiento-lavadomanos-entornos-educativos-retos-oportunidadestiempos-covid-19

81. https://www.campusvirtualsp.org/es/curso/ covid-19-precauciones-basicas-higiene-de-lasmanos-2020

82. https://espanol.cdc.gov/coronavirus/2019-ncov/ community/reopen-guidance.html. 7 may 2020

83. https://espanol.cdc.gov/coronavirus/2019-ncov/ community/organizations/cleaning-disinfection.html

84. https://www.epa.gov/pesticide-registration/list-ndisinfectants-use-against-sars-cov-2

85. https://www.bphc.org/whatwedo/infectious-diseases/ Infectious-Diseases-A-to-Z/Documents/Cleaning\%20 and\%20Disinfecting\%20for\%20COVID\%2019\%20 -\%20spanish.pdf

86. Buonanno M, Welch D, Shuryak I, Brenner DJ. La luz UVC lejana (222 nm) inactiva de manera eficiente y segura los coronavirus humanos en el aire. Informes Científicos 2020; 10 (1). doi: 10.1038/s41598-02067211-2.

87. Martínez-Sánchez G, Schwartz A, Donna VD. Potential cytoprotective activity of ozone therapy in SARS-CoV-2/COVID-19. Antioxidants (Basel) 2020; 9 (5): 389.

88. Marconcini S, Giammarinaro E, Covani U. The timeliness of ozone in the COVID era. Eur Rev Med Pharmacol Sci 2020; 24 (9):4625-4626.

89. Hernández A, Papadakos PJ, Torres A, González DA, Vives $M$, Ferrando $C$ et al. Two known therapies could be useful as adjuvant therapy in critical patients infected by COVID-19. Rev Esp Anestesiol Reanim 2020; 67 (5): 245-252.

90. Wang J, Shen J, Ye D, Yan X, Zhang Y, Yang W et al. Disinfection technology of hospital wastes and wastewater: Suggestions for disinfection strategy during coronavirus Disease 2019 (COVID-19) pandemic in China. Environ Pollut 2020; 262: 114665.

91. Rubio-Romero JC, Pardo-Ferreira MDC, TorrecillaGarcía JA, Calero-Castro S. Disposable masks: Disinfection and sterilization for reuse, and noncertified manufacturing, in the face of shortages during the COVID-19 pandemic. Saf Sci 2020; 129 : 104830.

92. Dev Kumar G, Mishra A, Dunn L, Townsend A, Oguadinma IC, Bright KR et al. Biocides and 
novel antimicrobial agents for the mitigation of coronaviruses. Front Microbiol 2020; 11: 1351.

93. Smith NL, Wilson AL, Gandhi J, Vatsia S, Khan SA. Ozone therapy: an overview of pharmacodynamics, current research, and clinical utility. Med Gas Res 2017; 7: 212-219.

94. Rowen RJ, Robins H, Carew K, Kamara MM, Jalloh MI et al. Rapid resolution of hemorrhagic fever (Ebola) in Sierra Leone with Ozone therapy. Afr J Infect Dis 2016; 10(1): 49-54.

95. Rowen RJ, Robins HR. A plausible "penny" costing effective treatment for corona virus-Ozone Therapy. J Infect Dis Epidemiol 2020; 6: 113.

96. Elvis AM, Ekta JS. Ozone therapy: A clinical review. J Nat Sci Biol Med 2011; 2 (1): 66-70.

97. Ricevuti G, Franzini M, Valdenassi L. Oxygen-ozone immunoceutical therapy in COVID-19 outbreak: facts and figures. Ozone Ther 2020; 5: 9014.

98. Semple JL, Moore GWK. High levels of ambient ozone (O3) may impact COVID-19 in high altitude mountain environments. Respir Physiol Neurobiol 2020; 280: 103487. doi: 10.1016/j. resp.2020.103487.

99. Silva EJNL, Prado MC, Soares DN, Hecksher F, Martins JNR, Fidalgo TKS. The effect of ozone therapy in root canal disinfection: a systematic review. Int Endod J 2020; 53 (3): 317-332.

100. Gérard V, Sunnen MD. SARS and ozone therapy: Theoretical considerations [cited in 2003]. Available from: http://www.triroc.com/sunnen/topics/sars.html

101. Tirelli U, Cirrito C, Pavanello M, Piasentin C, Lleshi A, Taibi R. Ozone therapy in 65 patients with fibromyalgia: an effective therapy. Eur Rev Med Pharmacol Sci 2019; 23: 1786-1788.

102. Murray BK, Ohmine S, Tomer DP, Jensen KJ, Johnson FB, Kirsi JJ et al. Virion disruption by ozone-mediated reactive oxygen species. J Virol Methods 2008; 153 (1): 74-77.

103. Alzain S. Effect of chemical, microwave irradiation, steam autoclave, ultraviolet light radiation, ozone and electrolyzed oxidizing water disinfection on properties of impression materials: a systematic review and meta-analysis study. Saudi Dent J 2020; 32 (4): 161-170.
104. Leon OS, Menendez S, Merino N, Castillo R, Sam $S$, Perez L et al. Ozone oxidative preconditioning: a protection against cellular damage by free radicals. Mediators Inflamm 1998; 7 (4): 289-294.

105. Zheng Z, Dong M, Hu K. A preliminary evaluation on the efficacy of ozone therapy in the treatment of COVID-19. J Med Virol 2020; 92 (11): 2348-2350.

106. Ricevuti G, Franzini M, Valdenassi L. Oxygen-ozone immunoceutical therapy in COVID-19 outbreak: facts and figures. Ozone Ther 2020; 5: 9014.

107. Guía sobre el uso del equipo de protección personal durante la pandemia COVID-19. Instituto Nacional de Ciencias Médicas y Nutrición Doctor Salvador Zubirán. Actualizado 27 abril 2020. Available in: http://www.incmnsz.mx/2020/Guia-equipo-deproteccion-INCMNSZ.pdf

108. Lineamiento técnico de uso y manejo del equipo de protección personal ante la pandemia por COVID-19. Gobierno de México [actualizado 12 de mayo de 2020]. Available in: https://coronavirus. gob.mx/wp-content/uploads/2020/05/Lineamiento_ uso_manejo_EPP

109. Guidance on Preparing Workplace for COVID-19. US department of labor. Available in: https://www. osha.gov/Publications/OSHA3990.pdf

110. Casas MML, Portes-Castro MA. Bioética y trasplantes electivos. Principio de proporcionalidad terapéutica. Cir Plast 2010; 20 (1): 43-48.

111. https://es.wikipedia.org/wiki/Principio_de_ precauci\%C3\%B3n

112. Sánchez E. El principio de precaución: implicaciones para la salud Pública. Gac Sanit 2002; 16 (5). Available in: http://scielo.isciii.es/scielo.php?script=sci_arttex $\mathrm{t} \& \mathrm{pid}=$ S0213-91112002000500001

Correspondence:

\section{M.D. Jesus Cuenca-Pardo}

Jerez 51, Mixcoac,

Benito Juárez, 03220,

Mexico City.

E-mail: jcuenca001@gmail.com

Conflict of interest: We declare that we have no conflict of interest. 

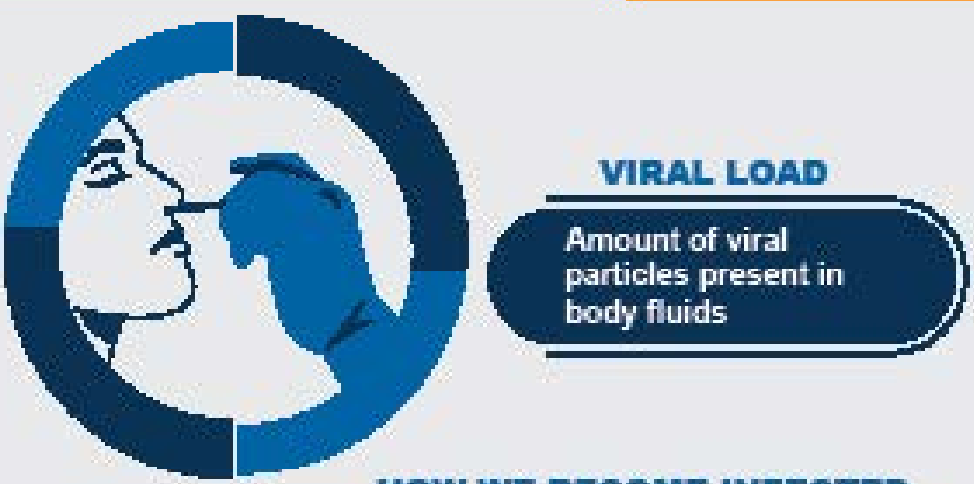

HOW WE BECOME INFECTED

Asymptomatic or presymptomatic people are the main source of infection. As the disease is more ostensible in the group of symptomatic patients, they tend to be more careful with less risk

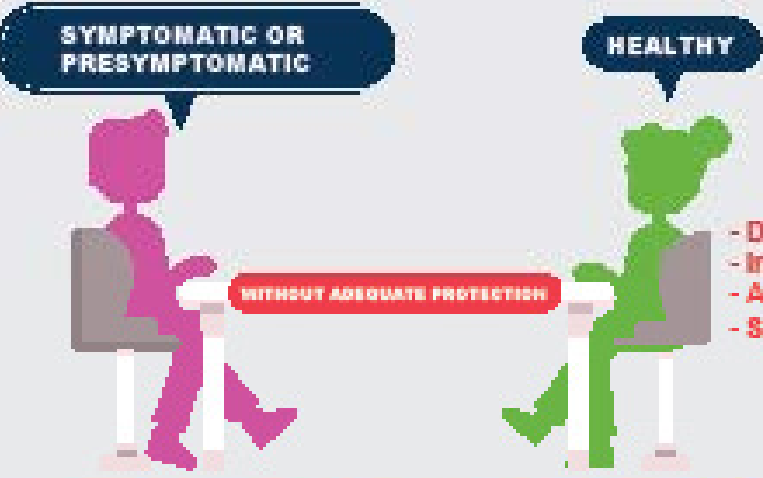

Direct transmisaion - Indirect transmiseion - Alr transmisalon Smoke in aurgical rooms

Several reports state that it is rare to get COVID by coming into contact with a contaminated surface or

during a fleeting encounter with a sick person.

AIR TRANSMISSION Respiratory secretions are expelled by the patients; they form aerosols with microparticles ( $<5$ microns) that remain in the air for several minutes and can be aspirated and deposited in the pulmonary alveoli.

\section{Respiratory secretions and other} body fluids are essential for the survival and transmission of the virus.

It has been considered as the main souree of eontagion of Covid 19.

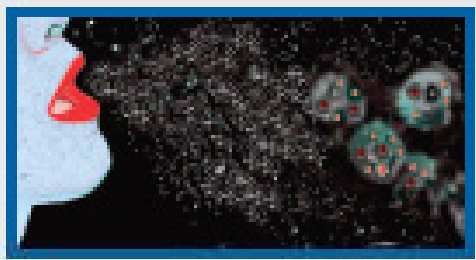

UTILITY OF QUANTIFYING VIRAL LOAD

- Severity of the infection

- Prognosis of the disease

- Risk of transmitting the infection

- Severity of the disease

- Evaluate the treatment

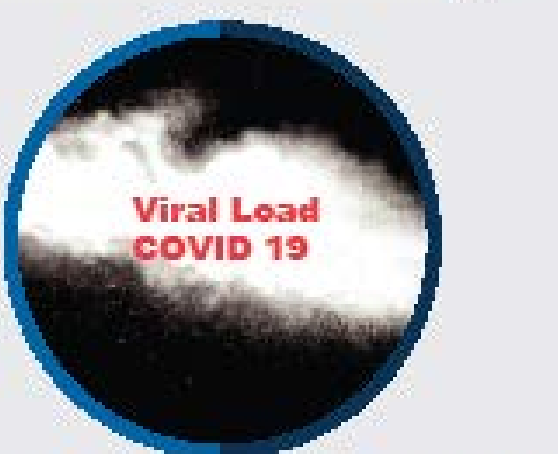

By reducing the viral load we can avoid contagion or make the disease milder.

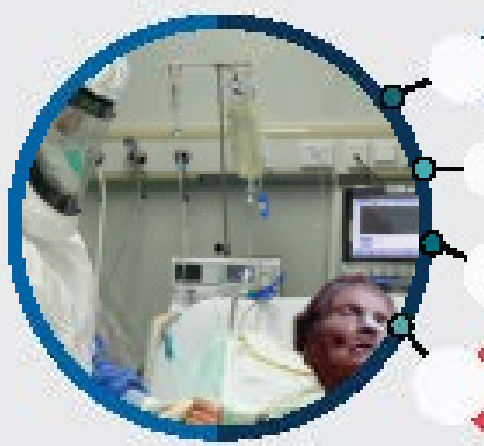

Blood $/$ plasma

Urine

Feces

Respiratory secretions

DIRECT TRANSMISSION CONTACT WITH FLUIDS WHERE THE SARS-COV 2 VIRUS HAS BEEN FOUND

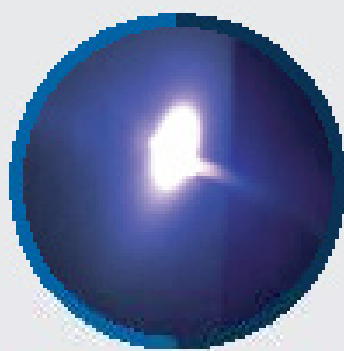

\section{AEROSOL FORMATION MECHANISM}

- Talking out loud or singing generate mleroparticles that can stay in the air up to 8 minutes.

- During coughing or sneezing, respiratory droplets are produced which can reach a distance of up to 8 meters. Maneuvers on the upper alrway or digastive tract produce large amounts of arrosols.
TRANSMISSION BY SURGICAL SMOKE

- It has been proved that aurglcal amoke particles measure from 0.05 to 25 microns.

- Surglcal smoke can contain HIV and hepatitis viruses.

- It could contain SARS-COV-2.

- There are no studles that demonatrate that surgical smoke

is a vehicle of transmiseion.

- The ues of enargy generating devices ahould be llmited. 


\section{SAFETY RECOMMENDATIONS \\ HOW TO REDUCE THE VIRAL LOAD.}

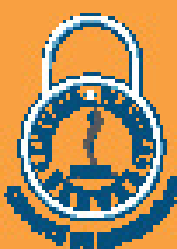

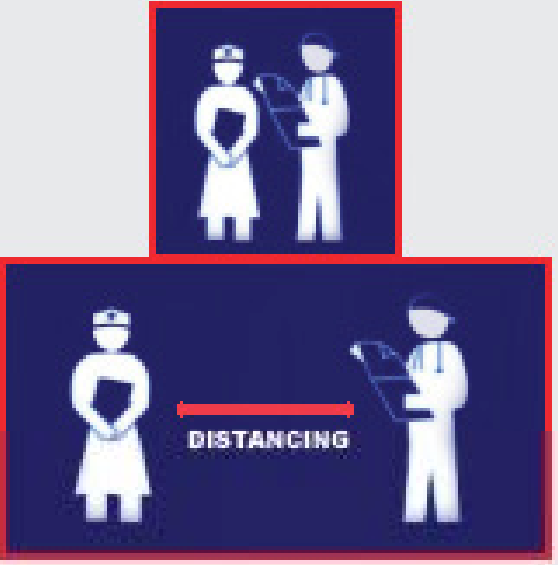

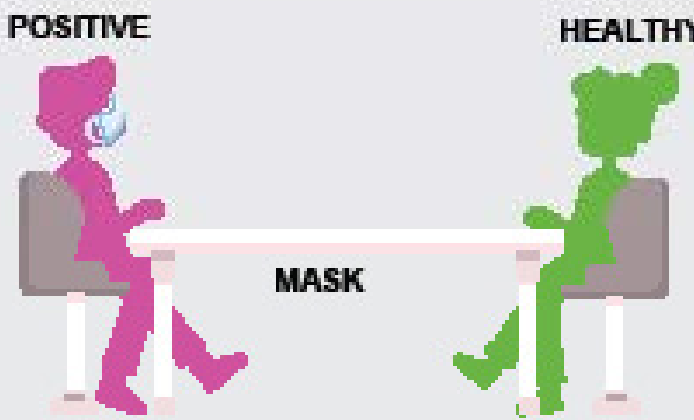

IF THE POSTTIVE PERSON USES A MASK, THE RISK OF CONTAGION IS REDUCED $30 \%$
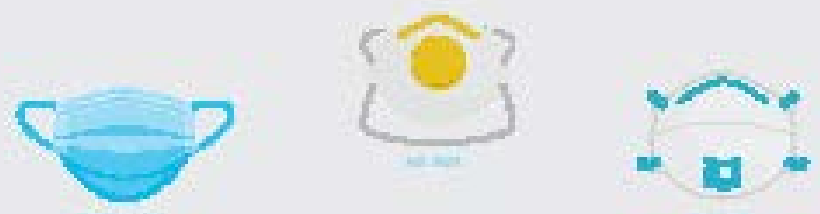

- Surgical masks retain particles > 10 microns.

- 195 and the llike nilter $95 \%$ of microparticles (5 microns).

- Resplrators with viral containment filters can retain particles $<1$ micron.

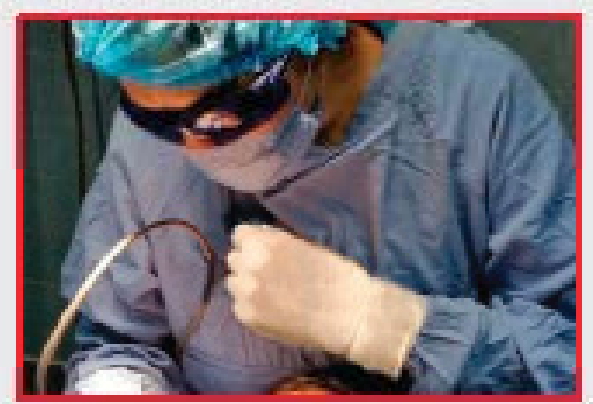

Eye protection with the use of goggles or glasses that reduce contagion by up to $10.6 \%$

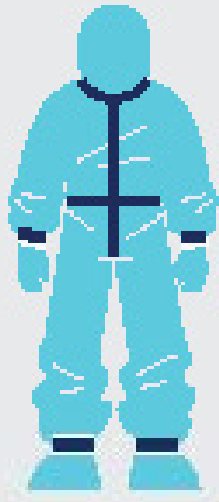

HOW TO REDUCE THE VIRAL LOAD

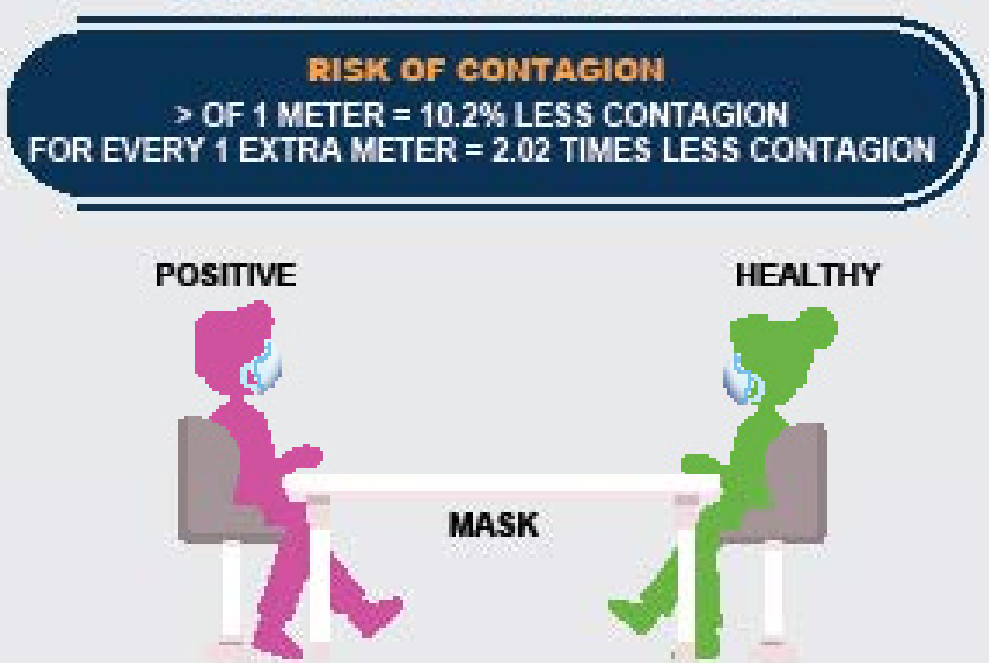

iF THE POSITIVE AND THE HEALTHY PERSONS USE A MASK, THE RISK OF CONTAGION IS LESS THAN $10 \%$

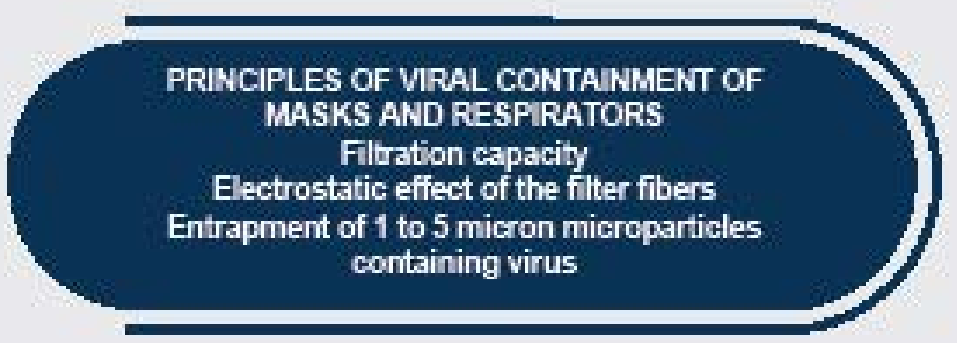

Masks retain particles between 5 to 10 microns. Respirators with viral containment filters can retain particles $<1$ micron

Respirators can contain up to 100 times more aerosol particles than a mask

\section{Respirators filter up to $97 \%$ of 5}

micron particles and have less effect on Eye protection with the use of goggles smaller particle 


\section{SAFETY RECOMMENDATIONS}

\section{HOW TO REDUCE THE VIRAL LOAD.}

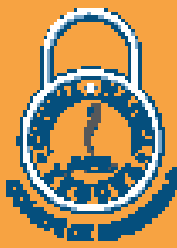

ALL PATIENTS SHOULD BE CONSIDERED AS SUSPICIOUS UNTIL THE DISEASE IS DISCARDED

\section{FIGURE 1. PROTECTIVE EQUIPMENT AND RECOMMENDED CARE IN THE CARE OF A PATIENT}

\begin{tabular}{|c|c|c|c|c|c|c|}
\hline $\begin{array}{l}\text { TYPE OF } \\
\text { RISK }\end{array}$ & JOB CHARACTERISTICA & TYPE OF CASE & $\begin{array}{l}\text { HAND } \\
\text { HYOIENE }\end{array}$ & $\begin{array}{l}\text { TYPE OF } \\
\text { MAsK }\end{array}$ & DISTARCE & OTHER MEASURES \\
\hline MINIrauta & $\begin{array}{l}\text { They have no contact } \\
\text { with unknown or } \\
\text { susplclous people or } \\
\text { Covid +. }\end{array}$ & $\begin{array}{l}\text { asymptomatic } \\
\text { patlents and general } \\
\text { public atthout } \\
\text { suspidion }\end{array}$ & $\begin{array}{l}\text { washing } \\
\text { and } \\
\text { dlatinfection }\end{array}$ & $\begin{array}{l}\text { clinical or } \\
\text { surglcal }\end{array}$ & $\begin{array}{l}\text { greater than } 1.5 \\
\text { meters. }\end{array}$ & $\begin{array}{l}\text { dlsinfect offices, } \\
\text { clinics and treatment rooms. } \\
\text { Awold using watting rooms }\end{array}$ \\
\hline MODERATE & $\begin{array}{l}\text { frequent contact with } \\
\text { unknown or susplclous } \\
\text { people or COVID * }\end{array}$ & $\begin{array}{l}\text { suspldious case } \\
\text { resplratory tract } \\
\text { Intection patient } \\
\text { non-aerosol } \\
\text { producers }\end{array}$ & $\begin{array}{l}\text { washing } \\
\text { and } \\
\text { disinfection }\end{array}$ & clnical o surgleal & $\begin{array}{l}\text { greater than } 1.5 \\
\text { meters }\end{array}$ & $\begin{array}{l}\text { eye protection } \\
\text { gloves } \\
\text { coat }\end{array}$ \\
\hline HIGH & $\begin{array}{l}\text { frequent exposure with } \\
\text { suspiclous or covid } \\
\text { posithe patients }\end{array}$ & $\begin{array}{l}\text { susplclous case } \\
\text { resplratory tract } \\
\text { Infectlon patient } \\
\text { producers of } \\
\text { serosols, Including } \\
\text { coughing and } \\
\text { sneezing }\end{array}$ & $\begin{array}{l}\text { washing } \\
\text { and } \\
\text { disinfection }\end{array}$ & $\begin{array}{l}\text { N95 mask or } \\
\text { similar }\end{array}$ & $\begin{array}{l}\text { greater than } 1.5 \\
\text { meters }\end{array}$ & $\begin{array}{l}\text { eye protection } \\
\text { gloves } \\
\text { coat }\end{array}$ \\
\hline VERY HIGH & $\begin{array}{l}\text { frequent exposure to } \\
\text { suspiclous sources or } \\
\text { posittre COVID } \\
\text { they perform procedures } \\
\text { on COVID + patents }\end{array}$ & $\begin{array}{l}\text { posithe case } \\
\text { producers of } \\
\text { serosols, Including } \\
\text { coughing and } \\
\text { sneezing } \\
\text { alreay or dlgesthe } \\
\text { maneuvers }\end{array}$ & $\begin{array}{l}\text { washing } \\
\text { and } \\
\text { disinfection }\end{array}$ & $\begin{array}{l}\text { N95 mask or similar } \\
\text { and foce shield. } \\
\text { respirators with } \\
\text { viral contsinment } \\
\text { fiters }\end{array}$ & $\begin{array}{l}\text { greater than } 1.5 \\
\text { meters }\end{array}$ & $\begin{array}{l}\text { eye protection } \\
\text { gloves } \\
\text { coat or overalls (preferable) }\end{array}$ \\
\hline
\end{tabular}

\section{PILLARS TO REDUCE THE VIRAL LOAD}

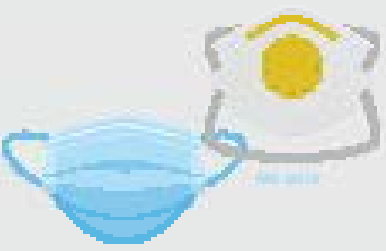

MASKS AND
RESPIRATORS

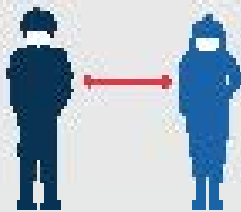

DISTANCE GREATER THAN $1.5 \mathrm{mts}$.

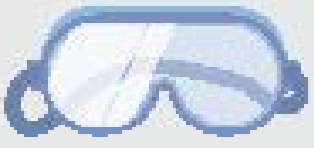

EYE PROTECTION

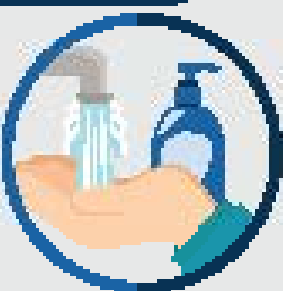

HAND

WASHING

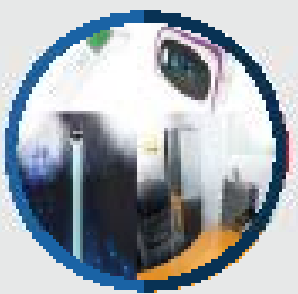

SANITIZATION AND PREPARATION OF THE ENVIRONMENT

THE BEST RESULT IS OBTAINED WITH THE COMBINATION OF ALL RECOMMENDATIONS

\section{MANDATORY AND UNIVERSAL RULES}
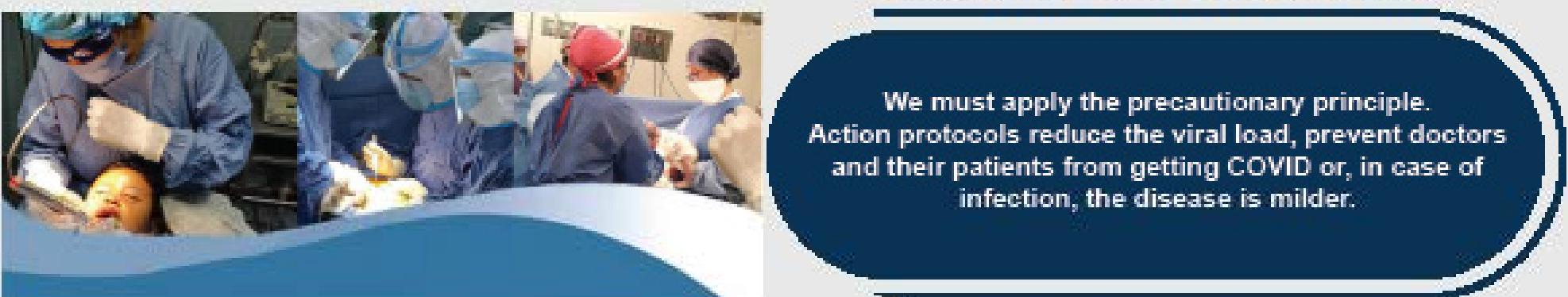